\title{
Synthesis of Epoxide and Polyol Compounds as Intermediates for Biolubricant from Soybean Oil
}

\author{
Muhammad Said", Bobbie Rizkie Mandhala Hermanto ${ }^{\#}$, Muhammad Aidil Defitra ${ }^{\#}$, Febri Sandi ${ }^{\#}$, RiskyVernando \\ ${ }^{\#}$ Chemical Engineering Department, Faculty of Engineering, Sriwijaya University, 30662, South-Sumatera Province, Indonesia \\ E-mail: saidm_19@yahoo.com
}

\begin{abstract}
Biolubricant derived from vegetable oils is one of alternatives to substitute petroleum based lubricant. The biolubricant is environmental friendly, biodegradable, non toxic and renewable since it is derived from the vegetable oils. Soybean oil is potential as raw material for synthesis epoxide compound as intermediate substances for biolubricant since it has properties of high viscosity, low volatility, thermal stablity, vaporization stability and biodegradable. Polyol compound was produced through hydroxylation process of epoxide compound derived from the vegetable oils. The research aims to synthesize the epoxide compound from soybean oil, polyol compound synthesis from the epoxide compound and to determine kinetic reaction constants of the epoxidation and hydroxylation reactions. The process synthesis of the epoxide compound, as well as, polyol was carried out in a stirred glass reactors equipped with temperature measurement. The epoxidation reaction was carried out at $60^{\circ} \mathrm{C}, 70{ }^{\circ} \mathrm{C}$, and $80{ }^{\circ} \mathrm{C}$ with reaction time of 30 to 180 minutes with 30 minutes interval, while the hydroxylation reaction was carried out at $45{ }^{\circ} \mathrm{C}, 50{ }^{\circ} \mathrm{C}, 55{ }^{\circ} \mathrm{C}$, and $60{ }^{\circ} \mathrm{C}$ with reaction time of 30 to 120 minutes with 30 minute interval. The highest conversion of soybean oil in epoxidation process was achieved $53.90 \%$ at $70^{\circ} \mathrm{C}$ and 120 minutes reaction time. The kinetic reaction constant for epoxidation reaction was achieved $\mathrm{k}_{\mathrm{ep}}=0.0046 \mathrm{~min}^{-1}$ at 70 ${ }^{\circ} \mathrm{C}$. The highest conversion of hydroxylation process was achieved $91.52 \%$ at $45{ }^{\circ} \mathrm{C}$ and 120 minutes reaction time. The kinetic reaction constant for hydroxylation reaction was achieved $k_{h d}=0.5528 \mathrm{~min}^{-1}$ at at $45{ }^{\circ} \mathrm{C}$.
\end{abstract}

Keywords — biolubricant; soybean oil; epoxidation; hidroxylation.

\section{INTRODUCTION}

Utilization of raw materials being sustainable and environmental friendly are sought to produce products of lower emissions and less waste. Renewable resources become interesting to be utilized for the raw materials fulfilling the sustainability and environmental friendly, as well as, for anticipating climate change. Energy mix in Indonesia in 2025 states that utilization of crude oil less than $20 \%$ while that of renewable energy more than $5 \%$ [1]. The energy mix policy can be achieved by using various sustainable resources for energy production such as biofuel which is environmental friendly. Automotive industry is designed to utilize biofuel in the combustion engine that produces low emission [2].

Crude oil is used as raw material for production of fuels such as gasoline, diesel fuel and kerosene, as well as, for production of lubricants. Crude oil and its derivations are compounds which cannot be degraded besides its price is fluctuated. Lubricants resulted from mineral oil base stocks was difficult to degrade and nondegradable $[3,4]$. Lubricants used in the parts of engine to reduce friction between the parts.
Fuels derived from crude oil are burnt to produce $\mathrm{CO}_{2}$ being potential for global heat since it is one of green house gases. Crude oil is unrenewable energy resources with limit resource while utilization of the crude oil for producing fuels and lubricants increases due to the increase of fuel and lubricants utilization for power plants, mining, agriculture, forestry, chainsaw oils, transmission oils, engine oils, hydraulic oils and trasportation [5]. Application of lubricants in industry is mainly for hydraulic fluids and engine oils for about $40 \mathrm{Mt} / \mathrm{yr}$ [6]. The use of lubricants in Indonesia reached 2,988,265 barrels in 2012 and it elevates 2 to $8 \%$ annually[7]. PT. Pertamina (Persero) had produced lubricants from the crude oils with the amount of $60 \%$ of consumption of lubricants while $40 \%$ of the lubricants were imported.

Lubricants produced either from crude oil or synthetic lubricants were added additives to improve physical properties of the lubricants when these were used in the machines to protect friction of the engine components and their wear, to lengthen the machine age or lifetime, to achieve energy efficiency, environment compatibility, safety, to control temperature through heat transfer and to prevent corrosion. Lubricants have properties such as stable to oxidation, hydrolysis, temperature, viscosity, viscosity index 
and corrosion. Ease movement between surfaces can be achieved when the lubricant is utilized [8].

Lubricants derived from crude oils can pollute land and water body since they are not degradable in the environment. Due to shortage of crude oil and to avoid the adverse effects of the lubricants derived from crude oils, biolubricants derived from renewable raw materials such as vegetable oils, starches, cassava, animal fats, or algae of biomass can be used as alternatives [9]. Biolubricant is suitable to be used in the engine parts due to its properties such as high viscosity, high degree of lubricity, low volatility and high flash point $[10,11]$.

Raw materials for lubricant base can be produced from petroleum, however due to its limited resources, renewable resources such as vegetable oils can be used as the raw materials. coconut palm oil, jartrophacurcas oil, soybean oil, corn oil, sun flower oil, coconut, olive and canola [12]. These vegetable oils are potential for synthesis of the biolubricants. The vegetable oils contain triglycerides as main compounds for sinthesizing biolubricants [13]. The fatty acid composition of the vegetable oils varies and it influences the chracteristics of biolubricants produced.

The advantages of using biolubricants from vegetable oils are renewable, stable to heat, high index viscosity, easy flowing, low emission, stable vaporization, high dissolution of additives, easy dissolution in other fluids, degradable, non toxic and environtmental friendly [14,15]. Degradation of biolubricants derived from vegetable oils shows higher degradability compared than lubricants derived from mineral oil. Polyol ester derived from vegetable oil expresses $62 \%$ degradability while lubricant of mineral oil base shows $34 \%$ degradability [16].

The biolubricants have disadvantages such as low oxidation stability due to unsaturated double bounds between atomic carbon in the lubricant and corrosion resistance. Additives are used to increase the oxidation stability, as well as, carrion property. The soybean oil is potential for the application as raw materials for biolubricant synthesis as it is planted in Indonesia and possesses the appropriate properties to be used as biolubricant.

Research on biolubricant synthesis had been conducted by former researchers. Synthesis of biolubricant from palm oil through biodiesel reaction with trimethylol propane to produce $97.8 \%$ yield of palm oil based trimethylolpropane ester at 4 hour and $130{ }^{\circ} \mathrm{C}$ [17]. Synthesis of biolubricant was carried out through esterification reaction with sulphated zirconia catalyst. Conversion of oleic acid with trimethylol propane using zirconia catalyst achieved $83.5 \%$, while with pentaerythritol reached $71.3 \%$ [18].

Pentaerythritoltetraoleate and trimethylolpropane ester was synthesized by reacting pentaerythritol and POME. The optimum reaction condition was achieved at $158{ }^{\circ} \mathrm{C}$, catalyst concentration $1.19 \%$, molar ratio $4.5: 1$ and reaction time of 60 minutes to obtain yield of $37.56 \%$ [19]. Lubrication test of trimethylolpropane (TMP) and pentaerythritol ester showed friction value of these biolubricants were suitable if these thesebiolubrants were used in vehicle engines [20]. Physicochemical properties and lubricating performance of Lunaria TMP ester indicates that it is potential for lubricant basestock [21]. Passion fruit and moringa oils epoxidized via performic acid is potential lubricants that satisfy tribological properties [22]. Biolubricant derived from avocado oil provides best friction and wear performance compared to other oils such as canola and olive oils [23]. The biolubricant derived from Tilapia oil provides extinguished biodegradability and viscosity index compared to oils based petroleum. Ester synthesized with 2-ethyl hexanol provides highest thermal stability compared to other long chain alcohols [24]. The former research was usually conducted at high temperature to gain high conversion. At low temperature, the yield was obtained $<50 \%$. Sinthesis of biolubricant at low temperature is more advantageous than that of high temperature in vapour phase since more energy is utilized. The research at this condition is useful to be conducted to obtain high conversion. Synthesis of biolubricant from soybean oil can be conducted through process of epoxidation, hydroxylation and acetylation at low temperature in liquid phase. The soybean oil can be used as raw material for biolubricant synthesis due to its high viscosity $\left(28,86 \mathrm{cSt}\right.$ at $\left.40{ }^{\circ} \mathrm{C}\right)$, high index viscosity (246), low pour point $\left(-9^{\circ} \mathrm{C}\right)$ and high flash point $\left(325^{\circ} \mathrm{C}\right)$.

The aims of research is to synthesize epoxy and polyol compound as intermediates of biolubricant from soybean oil, to study the effect of temperature and time of reaction to conversion and to determine reaction rate constants of epoxidation reaction, as well as, hydroxylation reaction.

\section{MATERIAL AND METHOD}

The epoxidation process, as well as, the hidroxilation one was conducted consequtively. Soybean oil was utilized as feed in the epoxidation reactor and it was converted into epoxy compound with various reaction temperature and time. The product of the epoxidation process, namely: epoxyde compound was fed into the hidroxilation reactor to obtain polyol as product. The characteristics of epoxyde compound in terms of density, viscosity, acid number and oxyrane number were determined. The density, viscosity, acid number and hydroxyl number were also determined to characterize the polyol compound.

\section{A. Synthesis of Epoxide Compound}

Soybean oil with the amount of $200 \mathrm{ml}$ was mixed with acetic acid $99 \%$ with the amount of $20 \%$ of the soybean oil weight. The mixture was fed to stirred glass reactor equipped with a hot plate. It was heated at $60{ }^{\circ} \mathrm{C}$. Hydrogen peroxide $30 \%$ with the amount of $65 \%$ of the soybean oil weight and sulphuric acid with the amount of $2 \%$ of the mixture weight were added to the mixture of the soybean oil and a etic acid. The process was repeated at temperature 70 and $80{ }^{\circ} \mathrm{C}$ and reaction time of 30 to 180 minutes with interval of 30 minutes. The mixture was cooled after the completion of the reaction. Sodium bicarbonate was dissolved in $200 \mathrm{ml}$ aquadest until the solution reached saturation. The mixture of reaction was withdrawn from the reactor and it was fed to separation flash. The saturated solution of the sodium bicarbonate and $200 \mathrm{ml}$ of aquadest were added to the reaction mixture and stirred. The mixture was neutralized and washed until $\mathrm{pH}$ value of the mixture become neutral. The mixture was left for 30 minutes to seprate the epoxy compound, water and other compounds. Sample of $0.5 \mathrm{~g}$ was analysis for the oxyrane number. Density, viscosity, acid number and iodium number was also analysed for each 
sample. The conversion and kinetic rate constant were determined at each temperature.

\section{B. Synthesis of Polyol Compound}

The epoxy compound, methanol for the amount of $70 \%(\mathrm{v})$ of the volume of the epoxy compound and bentonite of $1.5 \%$ of the epoxy compound were fed into the stirred glass reactor of $500 \mathrm{ml}$ equipped with hot plate and magnetic stirrer. The reactor was connected with the condenser. The hyroxilation process was conducted at various temperature $45{ }^{\circ} \mathrm{C}, 50{ }^{\circ} \mathrm{C}, 55{ }^{\circ} \mathrm{C}$, and $60{ }^{\circ} \mathrm{C}$ and the reaction time was varied from 30 to 120 minutes with 30 minutes interval. The mixture was inserted into separating flash to separate polyol, used bentonite and rest of methanol at the end of the process. The sample of polyol was analysed for its density, viscosity, oxyrane and hiroxyl number. Conversion, as well as, th kinetic rate constants were determined at each temperature condition.

\section{RESULTS AND DISCUSSION}

\section{A. Analytical Results of Soybean Oil}

The characteristics of soybean oil is shown in Table 1. Value of density, acid number and iod number fullfills the standard of the soybean oil characteristics.

TABLE I

SOYBEAN OIL CHARACTERISTICS

\begin{tabular}{|c|c|c|}
\hline Parameter & $\begin{array}{c}\text { Results of } \\
\text { Analysis }\end{array}$ & Standard \\
\hline Density, g/cm ${ }^{3}$ & 0.8360 & 0.917 \\
\hline $\begin{array}{c}\text { Viscosity, } \\
\text { poise }\end{array}$ & 0.471 & N/A \\
\hline $\begin{array}{c}\text { Acid number, } \\
\text { mg NaOH g } \\
\text { oil }\end{array}$ & 0.44 & Maximum 3 \\
\hline $\begin{array}{c}\text { Iod number, g } \\
\text { / 100 g oil }\end{array}$ & 131 & $129-143$ \\
\hline
\end{tabular}

B. Analysis of Density, Viscosity, and Acid Number of Epoxy Compound

Density, viscosity and acid number of epoxy compound are analysed with respect to temperature and time of epoxyde reaction. Density of epoxy compound with respect to temperature and time reaction is shown in Fig. 1 in which $\mathrm{d}_{1}$ curve at $60{ }^{\circ} \mathrm{C}, \mathrm{d}_{2}$ curve at $70{ }^{\circ} \mathrm{C}$ and $\mathrm{d}_{3}$ curve at $80{ }^{\circ} \mathrm{C}$. Curve The density of epoxy compound ranges between $0.8025-0.9052 \mathrm{~g} / \mathrm{cm}^{3}$. Density of epoxy compound increases as temperature and time of reaction increase. Density of the expoxy compound at constant time of reaction elevates along with temperature. The highest density is found at $0.9052 \mathrm{~g} / \mathrm{cm}^{3}$ at $80{ }^{\circ} \mathrm{C}$ and 180 minutes.

Measurement of viscosity of the epoxy compound was conducted before the hydroxylation process to acknowledge the viscous behaviour of the epoxy compound that relates to the fluid flowing. Results of analysis of epoxy compound are shown in Table 2. Values of viscosity increased along with the reaction time. The viscosity ranges from 0.4198 to
0.4524 poise at $60{ }^{\circ} \mathrm{C}$, from 0.4119 to 0.4537 poise at $70{ }^{\circ} \mathrm{C}$ and from 0.4403 to 0.4698 poise at $80{ }^{\circ} \mathrm{C}$. The lowest viscosity value of 0.4050 poise was obtained at $70{ }^{\circ} \mathrm{C}$ and 60 minutes reaction timewhile the highest one of 0.4697 poise was obtained at $80{ }^{\circ} \mathrm{C}$ and 180 minute reaction time. Viscosity values were influenced by the reaction condition and density of the compound.

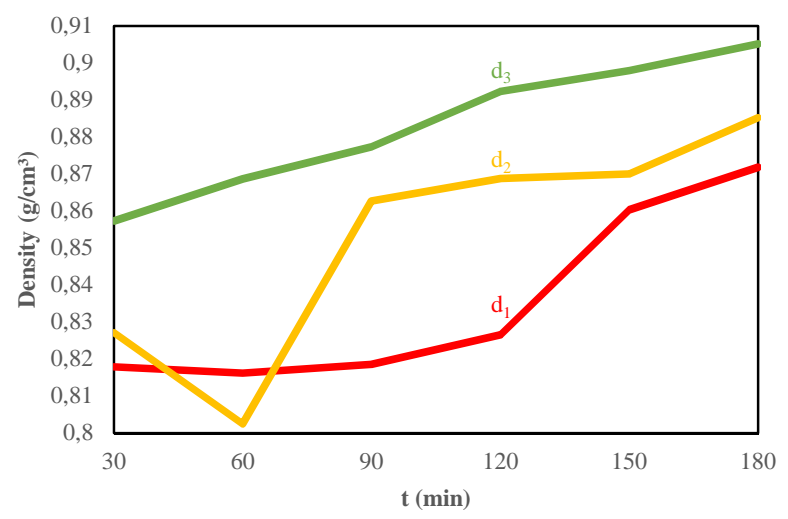

Fig. 1. Density of Epoxy Compound with respect to reaction time

TABLE III

RESUlTS OF ANALYSIS OF VISCOSITY OF EPOXY COMPOUND

\begin{tabular}{|c|c|c|c|}
\hline \multirow{2}{*}{ t (min) } & \multicolumn{3}{|c|}{ Viscosity at $\mathbf{4 0}^{\circ} \mathbf{C}$ (poise) } \\
\cline { 2 - 4 } & $\mathbf{T = 6 0}{ }^{\circ} \mathbf{C}$ & $\mathbf{T}=\mathbf{7 0}^{\circ} \mathbf{C}$ & $\mathbf{T}=\mathbf{8 0}^{\circ} \mathbf{C}$ \\
\hline 30 & 0.4198 & 0.4119 & 0.4403 \\
\hline 60 & 0.4152 & 0.4050 & 0.4598 \\
\hline 90 & 0.4442 & 0.4375 & 0.4538 \\
\hline 120 & 0.4132 & 0.4408 & 0.4625 \\
\hline 150 & 0.4456 & 0.4454 & 0.4681 \\
\hline 180 & 0.4524 & 0.4537 & 0.4698 \\
\hline
\end{tabular}

Acid number represents quantity of free fatty acid contained in the epoxy compound. The values of acid number are affected by temperature and the reaction time. The results of analysis of acid number of the epoxy compound are shown in Table 3. Acid number ranges from $0.384 \mathrm{mg} \mathrm{NaOH} / \mathrm{g}$ oil to $1.024 \mathrm{mg} \mathrm{NaOH} / \mathrm{g}$ oil at $60{ }^{\circ} \mathrm{C}$, from $0.344 \mathrm{mg} \mathrm{NaOH} / \mathrm{g}$ oil to $0.864 \mathrm{mg} \mathrm{NaOH} / \mathrm{g}$ oil at $70{ }^{\circ} \mathrm{C}$ and from $0.384 \mathrm{mg} \mathrm{NaOH} / \mathrm{g}$ oil to $0.768 \mathrm{mg} \mathrm{NaOH} / \mathrm{g}$ oil at $80{ }^{\circ} \mathrm{C}$. The lowest acid number was obtained $0.232 \mathrm{mg}$ $\mathrm{NaOH} / \mathrm{g}$ oil at $60{ }^{\circ} \mathrm{C}$ and 120 minutes. The acid number tends to increase with temperature and reaction time.

TABLE IIIII

ANALYTICAL RESUlts OF ACID NUMBER OF EPOXY COMPOUND

\begin{tabular}{|c|c|c|c|}
\hline \multirow{2}{*}{$\mathbf{t}(\mathbf{m i n})$} & \multicolumn{3}{|c|}{ Acid Number (mg NaOH / g oil) } \\
\cline { 2 - 4 } & $\mathbf{T = 6 0}{ }^{\circ} \mathbf{C}$ & $\mathbf{T}=\mathbf{7 0}^{\circ} \mathbf{C}$ & $\mathbf{T}=\mathbf{8 0}{ }^{\circ} \mathbf{C}$ \\
\hline 30 & 0.384 & 0,344 & 0,384 \\
\hline 60 & 0.336 & 0,376 & 0,424 \\
\hline 90 & 0.256 & 0,448 & 0,576 \\
\hline 120 & 0.232 & 0,968 & 0,656 \\
\hline 150 & 0.52 & 0.936 & 0.832 \\
\hline 180 & 1.024 & 0.864 & 0.768 \\
\hline
\end{tabular}




\section{The Effect of Temperature and Reaction Time to Oxyrane Number and Conversion}

Epoxidation reaction was conducted at $60{ }^{\circ} \mathrm{C}, 70{ }^{\circ} \mathrm{C}$ and $80{ }^{\circ} \mathrm{C}$ with reaction time from 30 to 180 minutes with 30 minutes interval. The reaction temperature was limited to 80 ${ }^{\circ} \mathrm{C}$ degradation of soybean oil as raw material. Increasing temperature. The use of hydrogen peroxide as strong oxidator to convert acetic acid having double bond between atom $\mathrm{C}$ and $\mathrm{O}$ to produce peroxy acid being reactive compound that can react fast with unsaturated compound.Peroxy acid reacts with triglyceride in soybean oil to form epoxy compound and acetic acid. In the epoxidation process, alkene bond is broken down to bind oxygen to promote the oxidation value. Acetic acid is used to form peroxy acid since it can mix with polar or no polar solvent. Sulfuric acid is used as catalyst to promote reaction of epoxidation.The epoxidation reaction proceeds as:

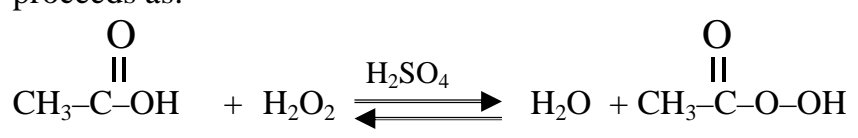

Carboxylic acid Peroxide hydrogen Water Peroxylate acid<smiles>COC(=O)C#CC=[W]</smiles><smiles>CC(=O)OOOC(C)=O</smiles><smiles>CCOC(=O)C#CC#N</smiles>

Peroxilate acid

Triglyceride<smiles>COC(=O)C1OC1(C)C</smiles>

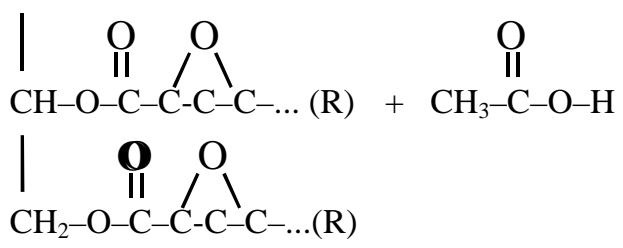

Epoxyde Carboxilyc Acid

Polyol compound is synthesized by reacting epoxy compound and methanol through hydroxylation process. During hydroxylation reaction, the oxyrane rings in the epoxyde compound opened by hydroxil groups by adding these groups to the oxyrane rings.

Formation of the epoxide compoundis indicated by increasing of oxyrane number. The oxyrane number indicates formation of oxyrane groups in the epoxide compound. Temperature and time of reaction affects the oxyrane number. The oxyrane number of the epoxide compound increased along with the reaction time and temperature. The oxyrane numbers with respect to temperature and time of reaction are shown in Fig. 2. As shown in Fig. 2, curve $\mathrm{n}_{1}$ is at $60{ }^{\circ} \mathrm{C}$, curve $\mathrm{n}_{2}$ is at $70{ }^{\circ} \mathrm{C}$ and curve $\mathrm{n}_{3}$ is at $80{ }^{\circ} \mathrm{C}$. The lowest oxyrane number was achieved 3.5617 at $70{ }^{\circ} \mathrm{C}$ and 30 minutes reaction time. The highest value of oxyrane number was achieved 8.2240 at 70 ${ }^{\circ} \mathrm{C}$.

The hydroxylation reaction proceeds as:

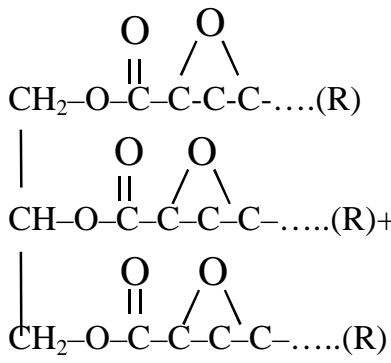

Epoxide Methanol<smiles>CCOC(=O)C(C)COC(=O)C(O)C(O)C(O)C(O)C(O)C(O)C(=O)OC</smiles>

Polyol

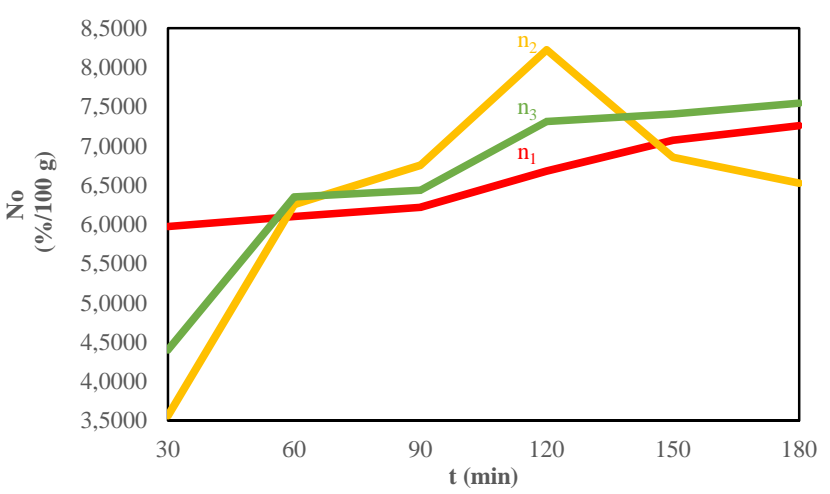

Fig. 2. Oxyrane Number of Epoxide Compound with respect to Temperature and Time of Reaction

Conversion of triglyceride of soybean oil was shown in Table 4. Conversion increased along the reaction time and temperature of reaction. Conversion ranges from 39.16 to 47.57 at $60{ }^{\circ} \mathrm{C}$, from 23.35 to 42.78 at $70{ }^{\circ} \mathrm{C}$ and from 28.89 to 49.45 at $80{ }^{\circ} \mathrm{C}$. The lowest coversion of $23.34 \%$ was achieved at $70{ }^{\circ} \mathrm{C}$ and reaction time of 30 minutes, while the highest one of $53.90 \%$ was achieved at $70{ }^{\circ} \mathrm{C}$ and 120 minutes reaction time. The small conversion is due to shorter contacts between soybean oil and peroxy compound. At temperature above $70{ }^{\circ} \mathrm{C}$, the conversion decreases as triglyceride degrades.

Comparison of epoxyde compound properties derived from Jatropacurcas $L$. and those derived from soybean oil are shown in Table 5. The epoxy compound derived from soybean oil possesses density, viscosity and acid number 
smaller than those of the epoxy compound derived from Jatropacurcas $L$.

TABLE IV

CONVERSION OF TRIGLYCERIDE IN SOYBEAN OIL

\begin{tabular}{|c|c|c|c|}
\hline \multirow{2}{*}{ (min) } & \multicolumn{3}{|c|}{$\mathbf{X}_{\mathbf{t g}}(\mathbf{\%})$} \\
\cline { 2 - 4 } & $\mathbf{T}=\mathbf{6 0}^{\circ} \mathbf{C}$ & $\mathbf{T}=\mathbf{7 0}^{\circ} \mathbf{C}$ & $\mathbf{T}=\mathbf{8 0}^{\circ} \mathbf{C}$ \\
\hline 30 & 39.16 & 23.35 & 28.89 \\
\hline 60 & 39.99 & 41.00 & 41.63 \\
\hline 90 & 40.75 & 44.28 & 42.17 \\
\hline 120 & 43.77 & 53.90 & 47.92 \\
\hline 150 & 46.37 & 44.92 & 48.57 \\
\hline 180 & 47.57 & 42.78 & 49.45 \\
\hline
\end{tabular}

The oxyrane number of the epoxy compound derived from soybean oil is higher than that of the epoxy compound derived from Jatropa curcas L. It indicates that the epoxy compound derived from soybean oil is sufficient as intermediate for biolubricant synthesis.

TABLE V

PROPERTIES COMPARISON OF EPOXYDE COMPOUND

\begin{tabular}{|l|c|c|}
\hline \multicolumn{1}{|c|}{ Characteristics } & $\begin{array}{c}\text { Epoxy } \\
\text { Compound } \\
\text { from Soybean } \\
\text { Oil }\end{array}$ & $\begin{array}{c}\text { Epoxy } \\
\text { Compound } \\
\text { from Jatropa } \\
\text { curcas L. }\end{array}$ \\
\hline Density, gr/ml & 0.86884 & $0.92-0.95$ \\
\hline Kinematic viscosity, cSt & 44.08 & 55 \\
\hline $\begin{array}{l}\text { Acid number, mg } \\
\mathrm{NaOH/g} \mathrm{compound}\end{array}$ & 0.968 & 1.50 \\
\hline $\begin{array}{l}\text { Oxyrane number, } \\
\% / 100 \mathrm{~g}\end{array}$ & 8.224 & 4.7 \\
\hline
\end{tabular}

\section{Kinetics of Epoxidation Reaction}

Reaction rate constants, $\mathrm{k}_{\mathrm{ep}}$, of epoxydation reaction at specified temperature is determined by plotting $\ln \left(1 /\left(1-\mathrm{x}_{\mathrm{ep}}\right)\right)$ versus $t$ as expressed in Equation (1) in which slope of the curve is $k_{e p}$. The reaction rate constants of epoxydation reaction are shown in Table VI. The $\mathrm{k}_{\mathrm{ep}}$ values increase as the temperature of epoxydation reaction inreases. It denotes the reaction speed elevates at higher temperature.

TABLE VI

RATE CONSTANTS OF EPOXYDATION REACTION

\begin{tabular}{|c|c|}
\hline $\mathbf{T}\left({ }^{\mathbf{0}} \mathbf{C}\right)$ & $\mathbf{k}_{\text {ep }}\left(\mathbf{m i n}^{\mathbf{- 1}}\right)$ \\
\hline 60 & 0.0045 \\
\hline 70 & 0.0046 \\
\hline 80 & 0.0048 \\
\hline
\end{tabular}

\section{E. Analysis of Density, Kinematic Viscosity and Acid Number of Polyol Compound}

Density of polyol compound with respect to reaction time and temperature is shown at Fig. 3 with curve $s_{1}=45^{\circ} \mathrm{C}, \mathrm{s}_{2}=$ $50{ }^{\circ} \mathrm{C}, \mathrm{s}_{3}=55{ }^{\circ} \mathrm{C}, \mathrm{s}_{4}=60{ }^{\circ} \mathrm{C}$. Density of polyol compound decreases along the reaction time. It increases as temperature increased from $45{ }^{\circ} \mathrm{C}$ to $60{ }^{\circ} \mathrm{C}$.As shown in Fig. 3, the density of polyol compound ranges between $0.85381-$ $0.86294 \mathrm{~g} / \mathrm{ml}$.

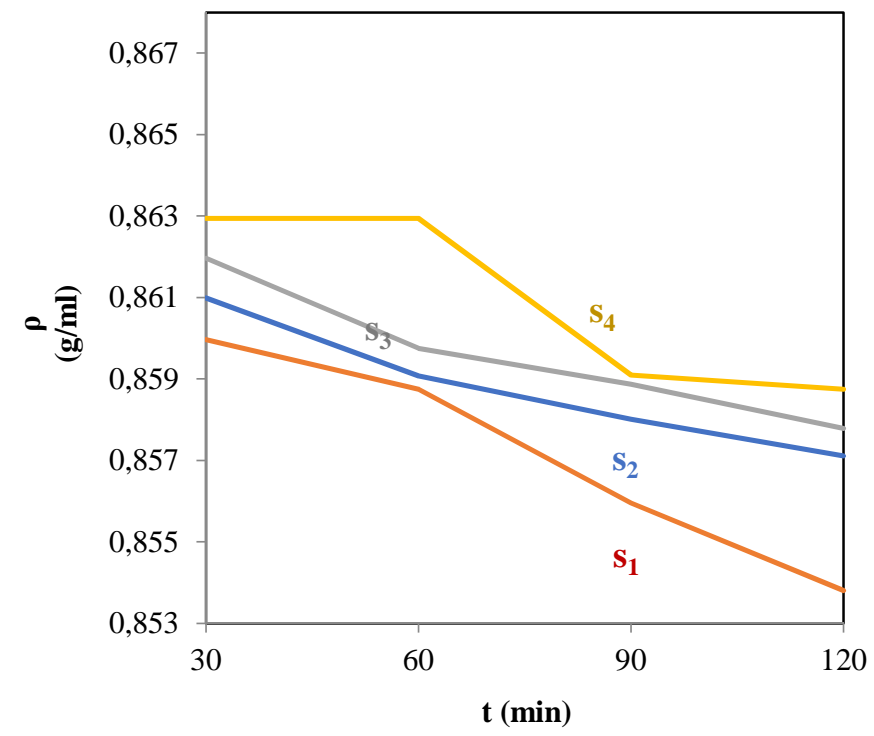

Fig. 3. Density of Polyol Compound with respect to Temperature and Time of Reaction

Analytical results of kinematic viscosity with respect to temperature and reaction time are shown in Figure 4 with curve $v_{1}=45{ }^{\circ} \mathrm{C}, v_{2}=50{ }^{\circ} \mathrm{C}, v_{3}=55^{\circ} \mathrm{C}, v_{4}=60{ }^{\circ} \mathrm{C}$. Kinematic viscosity increases at the elevated temperature. It decreases along the reaction time. Viscosity of polyol achieved 42.8246 as the lowest one measured at $45{ }^{\circ} \mathrm{C}$ and 120 minutes while the highest viscosity of $50.595 \mathrm{cSt}$ obtained at $60{ }^{\circ} \mathrm{C}$ and reaction time of 30 minutes.

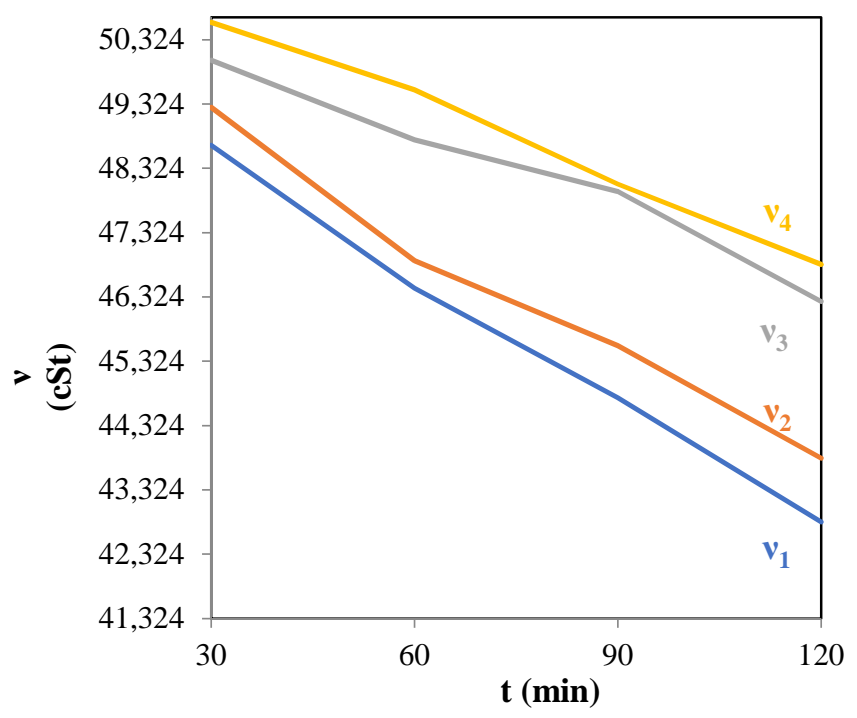

Fig. 4. Kinematic Viscosity of Polyol Compound with respect to Temperature and Time of Reaction

Acid number indicates quantity of free fatty acid contained in the polyol compound. Results of analysis of acid number is shown in Table 7. Acid numbers are affected by temperature and time of reaction. Acid number decreases at specified reaction as temperature is increased. As the reaction time increases, the acid numbers decrease. At temperature $60^{\circ} \mathrm{C}$, the values of acid number ranges from 0.3199 to 0.5034 with the increasing reaction time. It indicates at this temperature, quantity of fatty acid reduces. 
TABLE VII

REsults OF ANALysis OF ACID NuMBER OF POLYOL COMPOUND

\begin{tabular}{|c|c|c|c|c|}
\hline \multirow{2}{*}{$\mathbf{t}(\mathbf{m i n})$} & \multicolumn{4}{|c|}{ Acid Number $(\mathbf{m g} \mathbf{N a O H} / \mathbf{g}$ compound) } \\
\cline { 2 - 5 } & $\mathbf{T = 4 5}{ }^{\circ} \mathbf{C}$ & $\mathbf{T}=\mathbf{5 0}{ }^{\circ} \mathbf{C}$ & $\mathbf{T}=\mathbf{5 5}{ }^{\circ} \mathbf{C}$ & $\mathbf{T}=\mathbf{6 0}^{\circ} \mathbf{C}$ \\
\hline 30 & 1.2061 & 1.2111 & 1.1586 & 0.3188 \\
\hline 60 & 0.9887 & 0.9987 & 1.0200 & 0.4025 \\
\hline 90 & 0.87855 & 0.9853 & 0.9869 & 0.4579 \\
\hline 120 & 0.86909 & 0.9932 & 0.9777 & 0.5034 \\
\hline
\end{tabular}

F. The Effect of Temperature and Time to Hydroxil Number and Conversion of Epoxy Compound

Hydroxyl number was analysed to determine the amount of hydroxyl groups formed in the polyol compound. The results of analysis of hydroxyl number of polyol compound at various temperature and time of hydroxylation reaction are shown in Fig. 5 with curve $\mathrm{h}_{1}=45^{\circ} \mathrm{C}, \mathrm{h}_{2}=50^{\circ} \mathrm{C}, \mathrm{h}_{3}=55$ ${ }^{\circ} \mathrm{C}, \mathrm{h}_{4}=60{ }^{\circ} \mathrm{C}$. The hydroxyl number increases along with the reaction time indicating elevation of formation of hydroxyl groups in the polyol compound. Higher reaction time provides longer collision of molecules in the epoxy compound with those in methanol to form polyol compound. Formation of the polyol compound at $60^{\circ} \mathrm{C}$ result in lower hydroxyl number denoting lower polyol compound from due to decomposition of ofpolyol compounds forming compounds with lower molecular weight.

The results of analysis of oxyrane number of polyol compound are shown in Fig. 6 at various temperature and time of hydroxylation reaction with curve of $\mathrm{m}_{1}=45^{\circ} \mathrm{C}, \mathrm{m}_{2}=$ $50^{\circ} \mathrm{C}, \mathrm{m}_{3}=55^{\circ} \mathrm{C}, \mathrm{m}_{4}=60^{\circ} \mathrm{C}$. The oxyrane numbers at various operating condition in the reactor decrease along the reaction time as polyol compound formed from reaction of epoxyde compound with methanol. Reduction of the oxyrane numbers indicate the opening of oxyrane rings in the epoxyde compound to form the hydroxyl groups in the polyol compound as hydroxylation reaction proceeds. Conversion of epoxyde compound is determined from the theoxyrane number at temperature and time of reaction specified.

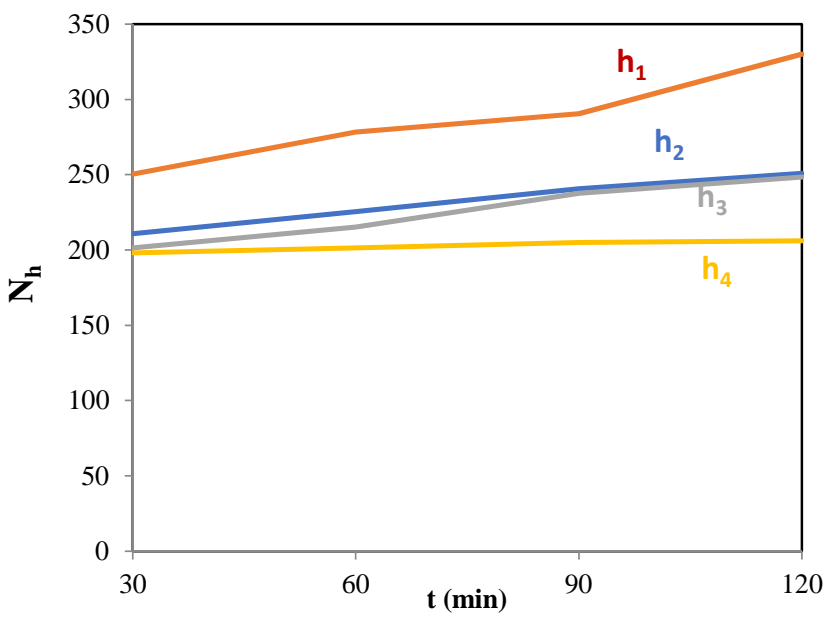

Fig.5. Hydroxyl Number of Polyol Compound

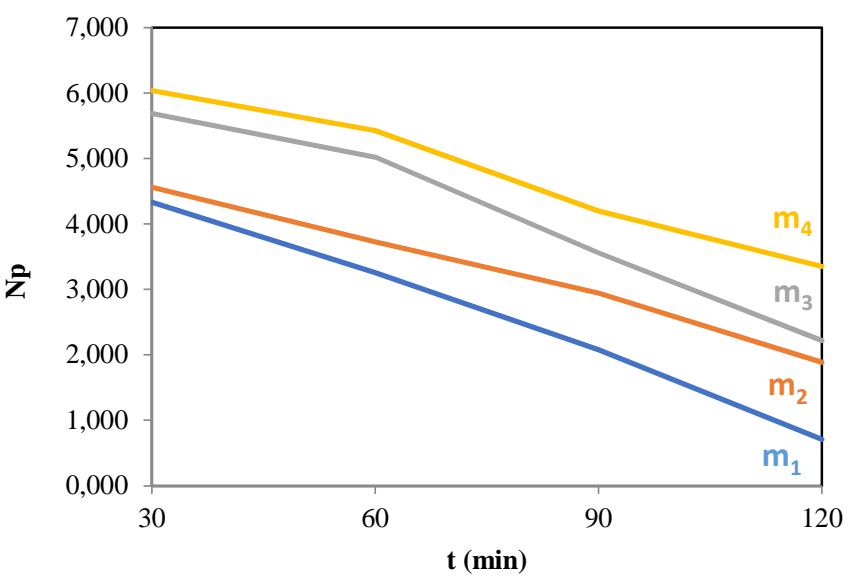

Fig.6. Oxyrane Number of Polyol Compound

Conversions of epoxide compound at various temperature and time of reaction are shown in Fig. 7 with curve $\mathrm{g}_{1}=45$ ${ }^{\circ} \mathrm{C}, \mathrm{g}_{2}=50{ }^{\circ} \mathrm{C}, \mathrm{g}_{3}=55{ }^{\circ} \mathrm{C}, \mathrm{g}_{4}=60{ }^{\circ} \mathrm{C}$. Conversion epoxyde compound is proportional to hydroxyl number. Conversion increases along the time of reaction, however, it decreases at higher temperature. Higher temperature promotes composition of epoxy compound to other products The smallest conversion of $27 \%$ at temperature $55{ }^{\circ} \mathrm{C}$ and reaction time of 30 minutes while the highest one is achieved $91.52 \%$ at $45^{\circ} \mathrm{C}$ and 120 minutes.

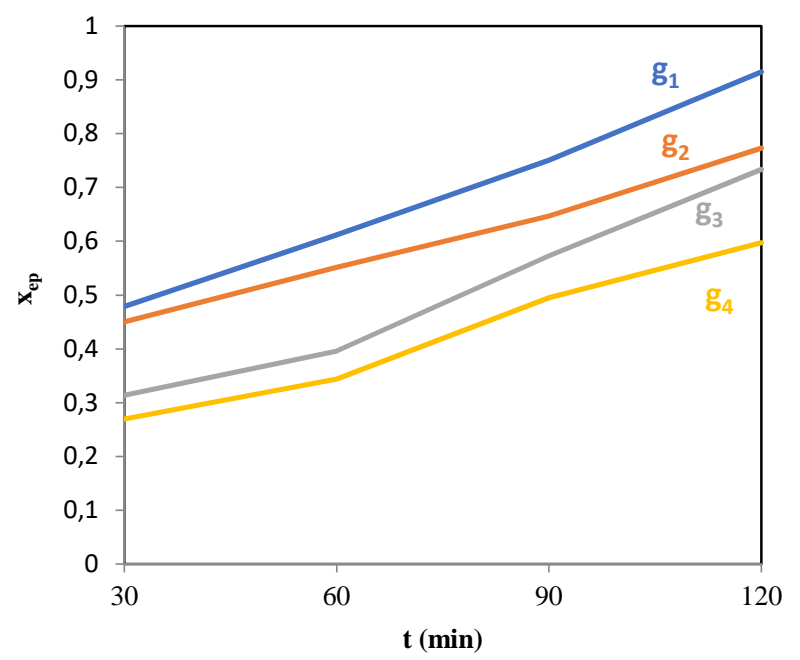

Fig.7. Conversion of Epoxide Compound

\section{G. Kinetic Rate Constants of Hydroxilation Reaction}

Kinetic rate constants are determined by assuming first order hydroxylation reaction by plotting $\ln \left(\mathrm{C}_{\mathrm{A} 0} / \mathrm{C}_{\mathrm{A}}\right)$ versus $\mathrm{t}$ in which reaction rate constant, $\mathrm{k}_{\text {hd }}$ being determined as slope of the curve. The rate constants for each reaction temperature is shown in Table 8.. Values of reaction rate constants are affected by temperature of the reaction. The highest $k_{h d}$ value of 0.5528 min- 1 is obtained at $40{ }^{\circ} \mathrm{C}$. 
TABLE VIII

REACTION RATE CONSTANTS

\begin{tabular}{|c|c|}
\hline $\mathbf{T}\left({ }^{\mathbf{0}} \mathbf{C}\right)$ & $\mathbf{k}{ }^{\prime \prime}\left(\mathbf{m i n}^{-1}\right)$ \\
\hline 45 & 0.5528 \\
\hline 50 & 0.3753 \\
\hline 55 & 0.3074 \\
\hline 60 & 0.2281 \\
\hline
\end{tabular}

\section{CONCLUSIONS}

Oxyrane number, as well as, conversion of soybean oil in the epoxydation process increases along reaction time at the elevated temperature. The highest conversion of $53.90 \%$ achieved at temperature of $70{ }^{\circ} \mathrm{C}$ and reaction time of 120 minutes. Kinetic rate constant at temperatureof $70{ }^{\circ} \mathrm{C}$ is $0.0046 \mathrm{~min}^{-1}$. The highest conversion of epoxy compound of $91.52 \%$ achieved at $45{ }^{\circ} \mathrm{C}$ and reaction time of 120 minutes. The kinetic reaction constant of $0.5528 \mathrm{~min}^{-1}$ of hydroxylation reaction was achieved at $45{ }^{\circ} \mathrm{C}$.

\section{NOMENCLATURE}

$\begin{array}{ll}\mathrm{C} & \text { Concentration of poliol } \\ \mathrm{k} & \text { Reaction rate constant } \\ \mathrm{t} & \text { Time of reaction } \\ \mathrm{x} & \text { Conversion }\end{array}$

$\operatorname{mmole} / \mathrm{ml}$
$\min ^{-1}$
$\min _{\%}$

\section{Greek Letters}

$v \quad$ Kinematic viscosity

$\rho$ Density

$\mathrm{cSt}$ $\mathrm{g} / \mathrm{cm}^{3}$

\begin{tabular}{ll}
\multicolumn{2}{l}{ Subscripts } \\
Ao & inlet \\
A & at time t \\
ep & epoxidation reaction \\
epo & epoxide \\
hd & hydroxylation reaction \\
tg & tryglicride
\end{tabular}

\section{ACKNOWLEDGMENT}

The authors thank to Chemical Engineering Department Faculty of Engineering Sriwijaya University for supporting the laboratory facilities and to Institution of Research and Community Service Sriwijaya University for financial support of the research.

\section{REFERENCES}

[1] Precidential Decree Republic of Indonesia No. 5, National Energy Policy, 2006.

[2] Y. Gerbig, S. I. U. Ahmed, F. A. Gerbig, and H. Haefke, "Suitability of vegetable oils as industrial lubricants," Journal of Synthesis Lubricant, vol. 21, pp. 177 - 191, Oct. 2004.

[3] S. Gupta, R. Kumar, S. Tyagi, and P. V. C. Rao, "Using microwave technology in biolubricants production enhances product yields and reduces reaction time," (2012) Production of biolubricant base stock. [Online]. Available : www.digitalrefining.com/article/1000654.

[4] M. Y. Koh., T. I. M. Ghazi., and A. Idris, "Synthesis of palm based biolubricant in an oscillatory flow reactor (OFR), " Industrial Crops and Products, vol. 52, pp. 567 - 574, Oct. 2013.
[5] J. McNutt and Q.S. He, "Development of biolubricants from vegetable oils via chemical modification, " Journal of Industrial and Engineering Chemistry, vol. 36, pp. 1-12, Feb. 2016.

[6] J. C. J. Bart, E. Gucciardi, and S. Cavallaro, Biolubricants Science and Technology, 1st ed., Cambridge : Woodhead Publishing Limited, 2013.

[7] BPS, Produksi Bahan Bakar Minyak, 2014.

[8] A. R. Lansdown, Tribology in Practice Series : Lubrication and Lubricant Selection: A Practical Guide, 3rd ed., ASME Press, Champaign, IL, 2004.

[9] J. Hagstrom, USDA to Set Requirements for Agencies to Purchase Bio-based Products, in Govexec.com (2005).

[10] S. M. Alves, B. S. Barros, M. F. Trajano, K. S. B. Riberiro, and E. Moura, "Tribological behaviour of vegetable oil-based lubricants with nanoparticles of oxides in boundary lubrication conditions," Tribology International Journal, vol. 65, pp. 28 - 36, Apr.2013.

[11] P. Nagendramma and S. Kaul, "Development of ecofriendly/biodegradable lubricants: An overview," Journal of Renewable and Sustainable Energy Review, vol. 16, pp. 764 - 774, Oct. 2011.

[12] R.V. Sharma and A. K. Dalai, "Synthesis of bio-lubricant from epoxy canola oil using sulfated Ti-SBA-15 catalyst, " Journal of Applied Catalyst B: Environment, vol. 142, pp. 604-614, June 2013.

[13] D. Kania, R. Yunus, R. Omar, S. A. Rashid, and B. M. Jan, "A review of biolubricants in drilling fluids: Recent research, performance, and applications, "Journal of Petroleum Science and Engineering, vol. 135, pp. 177-184, Sept. 2015.

[14] F. M. T. Luna, B. S. Rocha, E. M. R. Jr, M. C. G. Alburqueque, D. C. S. Azevedo, and C. L. C. Jr, Assestment of biodegradability and oxidation stability of mineral, vegetable and synthetic oil samples" Journal of Industrial Crops and Products, vol.33, pp. 579-583, Jan.2011.

[15] C. S. Madankar, A. K. Dalai, and S. N. Naik, Green synthesis of biolubricant base stock from canola oil,"Journal of Industrial Crops and Products, vol. 44, pp. 139-144, 2013.

[16] J. W. Bredsguard, T. D. Thompson, S. C. Cermak and T. A. Isbell, Environmentally Friendly and Biobased Lubricants, Milton : CRC Press LLC, 2016.

[17] E. K. Heikal, M.S. Elmelawy, S. A. Khalil, and N. M. Elbasuny, "Manufacturing of environment friendly biolubricants from vegetables oils," Egyptian Journal of Petroleum, vol 26, pp. 53 - 59, March 2016.

[18] J. Oh, S. Yang, C. Kim., I. Choi., and J. H. Kim, " Synthesis of biolubricants using sulphated zirconia catalysts," Applied Catalyst A: General, vol. 455, pp. 164 - 171, Jan. 2013

[19] R. Yunus, A. Fakhru'IRazi, T. L. Ooi, R. Omar, and A. Idris, "Synthesis of palm oil based trimethylolpropane esters with improved pour points, "Industrial Engineering Chemical Research, vol. 44, pp. $8178-8183$, Sept. 2005.

[20] N. W. M. Zulkifli, S. S. N. Azman, M. A. Kalam, H. H. Masjuki, R. Yunus, and M. Gulzar, "Lubricity of bio-based lubricant derived from different chemically modified fatty acid methyl ester, “Tribology International, vol. 93, pp. 555 - 562, March 2015.

[21] G.S. Dodos, D. Karonis, F. Zannikos, and E. Lois, "Renewable fuels and lubricants from Lunaria апnиa L, “ Journal of Industrial Crops and Products, vol. 75, pp. 43-50, May 2015.

[22] M.S. Silva, E.L. Foletto, S.M. Alves, T.N.C. Dantas, and A.A.D. Neto, "New hydraulic biolubricants based on passion fruit and moringa oilsand their epoxy, "Journal of Industrial Crops and Products, vol. 69, pp. 362-370, Feb. 2015.

[23] C.J. Reeves, P. L. Menezes, T. C. Jen, and M. R. Lovell, "The influence of fatty acids on tribological and thermal properties of natural oils as sustainable biolubricants, " Tribology International, vol. 90, pp. 123-134, Apr. 2015.

[24] C. P. D. Valle, J. S. Rodrigues, L. M. U. D. Vechine, A. P. Cunha, J. Q. Malveira, and F. M. T. Luna, N. M. P. S. Ricardo, "Chemical Modification of Tilapia oil for biolubricant applications," Journal of Cleaner Production, vol. 191, pp. 158 -166, Apr. 2018. 